\title{
MANUFACTURE AND PERFORMANCE VALUATION OF POULTRY PLUCKER SUITABLE FOR SMALL FARMS
}

\author{
Mady, M. A. A.* and A. R. Obaia**
}

\begin{abstract}
A study was carried out to manufacture and evaluate of a poultry feather plucking machine to select appropriate operational parameters. The performance evaluation tests were conducted under different factors such as, machine drum rotary speeds of 240, 340, 440 and 560 rpm (6.4, 9.07, 11.74 and $14.95 \mathrm{~m} / \mathrm{sec}$.), scalding times of chicken of 30, 60 and 90 sec and number of machine fingers of 72, 90 and 108. The results show that, the highest average plucking efficiency of $91.4 \%$ was obtainable with machine rotary speed of 240 rpm, scalding time of 30 seconds and number of machine fingers of 108. The lowest average was $43.73 \%$ at the speed of 560 rpm and scalding time of 90 seconds. In general, the results revealed that, the machine plucking efficiency decreased with an increase in machine speed and scalding time. Generally it can be said that, the machine rotary speed, scalding time and number of machine fingers plays an important role in improving the de-feathering. The operation cost of the poultry feather plucking machine was $0.3 \mathrm{LE}$. $\mathrm{kg} / \mathrm{h}$, this means that, the operation cost for chicken ( $2 \mathrm{~kg}$ ) was $0.6 \mathrm{LE}$., the poultry feather plucking machine reduce 2.40 LE for each chicken as compared with the price of the operation cost of the poultry feather plucking in the chicken ship.
\end{abstract}

\section{INTRODUCTION}

7 he continuous increase in human population needs an increase in food production to cover their nutritional requirements. One of the most important nutrients needed for humans and ought to be increased is the animal protein.

\footnotetext{
* Assoc. Prof.; Agric. Eng. Dept.; Fac. of Agric. Suez Canal University, Ismailia.

**Egypt. Agric. Eng. Res. Institute, ARC, Dokki, Giza, Egypt.
} 
In Egypt, the poultry industry has experienced rapid growth in both production and consumption from 1980 up to now, the commercial production of broilers for meets increased by $100 \%$. Over 1200 million chicken produce about 1500 million-ton weight of meat each year ( i.e. equal to 87\%) from the total consumption and import 150 million chicken ( i.e. equal to 13\%) from the total consumption (Industry and Commerce Ministry and Stock of poultry 2017 in Arabic reference).

David, 1999. There are three ways in which feathers can be removed completely from the chicken. The first is for broilers only and is by hand. The feathers are simply pulled from the carcass and placed in a feather bin. This method takes a lot of time. It is tedious and results in low output. The second method is by holding the carcass against rubber fingers protruding from a continuously rotating horizontal drum. The third method uses a bowl de-feather. Scaled birds, to a weight specified by the manufacturer, are placed in the bowl de-feather chute which passes into the body of the machine, the machine is stopped and a door to the bottom of the machine is opened. The plucked carcasses emerge ready for further processing. Time taken in the bowl de-feather will depend on the nature of the bird, its age and condition. Feathers that might have been soaked in hot water; and making the price of processed poultry products cheap. Again, tearing of carcass skin during the plucking process in the slaughter house has become one of the major economic problems during processing.

Ogundipe, 2002. The de-feathering machine saves time, easy to operate and better picking is achieved. Mechanical de-feathering employs various de-feather mechanism such as rubber finger, rotating plate, drum and angle bar mechanism. This is done after slaughtering the birds which is accompanied by bleeding period. The carcass is removed and lowered into a tank of heated water to a certain temperature and plucked. The use of de-feathering machine in processing poultry has contributed tremendously to the successful processing of dressed and hygienic chicken for consumption.

Hegazy, 2003. Stated that, the best ever results were obtained after modifying the horizontal drum type machine, at plucking cylinder speed of $(5.9 \mathrm{~m} / \mathrm{s})$, minimum degree of rubber finger stiffness $(0.15 \mathrm{~N} / \mathrm{mm})$ and 
stagger distribution system of rubber fingers on the cylinder surface. At these levels a high-quality birds were obtained through. Where, the mechanical damaged of exposed flesh decreased with about 28.7 and $23.07 \%$, the mechanical damaged decreased with about 3.49 and $37.29 \%$ for breast and legs and carcass elsewhere, respectively.

Buckland, 2005. The objective of a centralized poultry processing paltry of any scale of operation is to produce hygienic, wholesome, attractive and saleable of consistent appearance and quality of high standard.

Jekayinfa, 2005. Poultry processing plant meat products have gained a lot of markets in the world today. The daily demand for the products is always being meet because of the increasing mechanization of the poultry farming. Most mechanized plant out of three plants that were taken into consideration required less energy consumption where there would be also corresponding increase in daily production beyond daily consumption by the poultry consumers to the extent that the system undoubtedly called for preservation by the use of refrigerator immediately after processing.

Adejumo et al. 2013. A developed poultry feather plucking machine was evaluated using two breed (Isa Brown layer and Cockerel) at the machine speed of 225, 312, 369 and 426rpm, and scalding time of 30,60 and 90 seconds. The left over feather on bird after machine operation were manually plucked and plucking efficiency calculated on mass basis. The results show that the machine performance on cockerel has highest plucking efficiency. The plucking efficiency decreased as the machine speed and scalding the increased. The overall mean performance was $67.65 \%$ and the maximum plucking efficiency of $99.43 \%$ was obtained on cockerel at $225 \mathrm{rpm}$ and 30 seconds scalding time.

Lucas and Adetola, 2013. The conversion of a live chicken into safe and wholesome meat products suitable for human consumption takes place in a series of processing steps. Few of the processes require force to carry it out successively among which are slaughtering and de-feathering. The latter is the focus in this paper, plucking force of chicken produced from two breeds of chicken. Each sample of the chicken carcass was loaded into the hanger and lowered into the rotary drum for plucking one at a time. The process took an interval of one minute from one temperature to 
another in order to determine the appropriate plucking force. The results obtained for plucking contour and down feather of local chicken carcass were $11.26 \mathrm{~N}$ and $2.44 \mathrm{~N}$ respectively at $85 \mathrm{oC}$ for 5 minutes. The corresponding values for the exotic breed carcass in the order listed above are $4.13 \mathrm{~N}$ and $1.02 \mathrm{~N}$ respectively at temperature of $70 \mathrm{oC}$ for 3 minutes. The results obtained showed that the two samples of chicken examined would meet-up with daily demand in relation to production rate domestically.

Adetola et al., 2014. The removing feathers by hand is the traditional means and method of removing feathers from poultry species. For certain reasons, removing feathers by hand was becoming obsolete since the inception of industrial age. Development of a poultry de-feathering machine is a process of producing a mechanical means of removing feathers from scalded birds. The efficiency at each trial was determined and average efficiency was calculated to be approximately $95 \%$

Tanimola et al., 2014. De-feathering of the birds is one process which is time consuming and cumbersome. It involves a process of removing the feather from birds and this is commonly done manually which results in waste of time, low output and injury. In order to make de-feathering process easy, a de-feathering machine was designed and developed. Tests were carried out using birds of different weights and efficiency of $98 \%$ was achieved

Adesanya and Olukunle, 2015. A chicken de-feathering machine was designed and fabricated de-feathering machine for small scale poultry processors and evaluated the performance of the machine. It was observed that at constant speed $(300 \mathrm{rpm})$ and at time interval of 5 seconds, the mass of feather removed was found to be 38.35, 31.72, 25.15 $\mathrm{g}, 19.25,12.50 \mathrm{~g}$ and $0 \mathrm{~g}$, respectively. The total mass of feather removed was $126.97 \mathrm{~g}$. During the de-feathering process, it was found that the flesh of the chicken was not damaged. Consequently, the machine capacity was found to be 1 bird per 25 seconds while the machine efficiency was $95 \%$.

Ugwu et al., 2015. The top-table chicken feather plucking machine was optimized to top style chicken feather plucking machine and its performance was evaluated. The machine was evaluated using five 
different species of chicken at three different speeds of $400 \mathrm{rpm}, 450 \mathrm{rpm}$ and 500rpm. The results obtained showed that the machine performed highest at an average efficiency of $84.49 \%$ at the speed of $400 \mathrm{rpm}$ on average time of 22.8 seconds. The analysis of variance of the results obtained showed that speed and species of chicken.

The aim of this study was manufacture and performance evaluation to select appropriate operational parameters for the poultry feather plucking machine. During the experiments, the following parameters were examined:

- Four different machine speed 240, 340, 440 and $560 \mathrm{rpm}(6.4,9.07$, 11.74 and $14.95 \mathrm{~m} / \mathrm{sec}$ )-

- Three different scalding time (30, 60 and $90 \mathrm{sec}$.$) .$

- Three different no. of machine fingers (72, 90, and 108 finger).

\section{The plucking feather machine performance was studied through:}

- The mechanical and manually plucked feather weight

- The plucking feather efficiency:

- The plucking feather machine cost:

\section{MATERIALS AND METHODS}

To accomplish the objective of this study, a plucking feather machine has been manufactured and its performance evaluation was conducted. The technical specifications and operating parameters of the developed unit are as shown in table (1).

\section{Description of the Machine:}

The plucking feather machine consists of the cylinder, the rotating plate and the frame. The frame of the machine of $(90 \times 60 \times 50 \mathrm{~cm})$, the cylinder of $53.6 \mathrm{~cm}$ diameter; $47 \mathrm{~cm}$ length and $2 \mathrm{~mm}$ thickness. Number of rows fingers 3 rows. Number of fingers in one row 20 fingers. Total number of fingers 60 fingers. Stager distribution system of rubber finger on the cylinder. Diameter of finger opening $2 \mathrm{~cm}$. The rotating plate of $51 \mathrm{~cm}$ diameter. Number of rows fingers on the rotating plat 4 rows. Total number of fingers 48 fingers. The feather plate is located at the base of the plucking cylinder. 
Table 1: The technical specifications and operating parameters of the developed unite.

\begin{tabular}{|c|c|}
\hline Technical specifications & Dimension \\
\hline $\begin{array}{l}\text { Total main frame: } \\
\text { Total length, mm. } \\
\text { Total width, mm. } \\
\text { Total height, mm. }\end{array}$ & $\begin{array}{l}900 \\
600 \\
970\end{array}$ \\
\hline $\begin{array}{l}\text { Cylinder } \\
\text { Diameter, mm. } \\
\text { Height, mm. } \\
\text { Number of rubber finger. } \\
\text { System of number on the } \\
\text { cylinder. }\end{array}$ & $\begin{array}{c}536 \\
470 \\
48 \\
\text { Stager distribution } \\
\text { system }\end{array}$ \\
\hline $\begin{array}{l}\text { Rotating plat } \\
\text { Diameter } \\
\text { No. of rubber finger on the plat. } \\
\text { System of number on the plat. }\end{array}$ & $\begin{array}{c}510 \\
48 \\
\begin{array}{c}\text { Stager distribution } \\
\text { system }\end{array}\end{array}$ \\
\hline $\begin{array}{l}\text { Main frame } \\
\text { Total length, mm. } \\
\text { Total width, mm. } \\
\text { Total height, mm. }\end{array}$ & $\begin{array}{l}900 \\
600 \\
500 \\
\end{array}$ \\
\hline $\begin{array}{l}\text { Electric motor } \\
\text { Power, hp. } \\
\text { No. of rotary speed(rpm). }\end{array}$ & $\begin{array}{l}1 \mathrm{hp} \\
1400\end{array}$ \\
\hline
\end{tabular}

Also, Stager system distribution of rubber finger on the rotating plat. Two pulleys (60 and $350 \mathrm{~mm}$ diameters) fixed on each of motor and drum shaft respectively. The belt length was $440 \mathrm{~mm}$ and the powered by an electric motor $(1 \mathrm{Hp})$. The electric motor was connected by Inverter device (AC650 series) to provide or reduce the rotary speed of the electric motor. as shown in Fig 1-a, b and Fig. 2-a, b.

\section{Theory of machine working:}

The poultry to be de-feathered are soaked in hot water for one minute, and then introduced into the drum through an opening on the drum. The engine is then switched on, as the rotating disc laden with the spikes rotates, the chicken rubs with the spikes attached to the drum. This 
rubbing with the spikes, causes the feather to peel off from the chicken within a short time. The feathers are there by separated from the chicken.
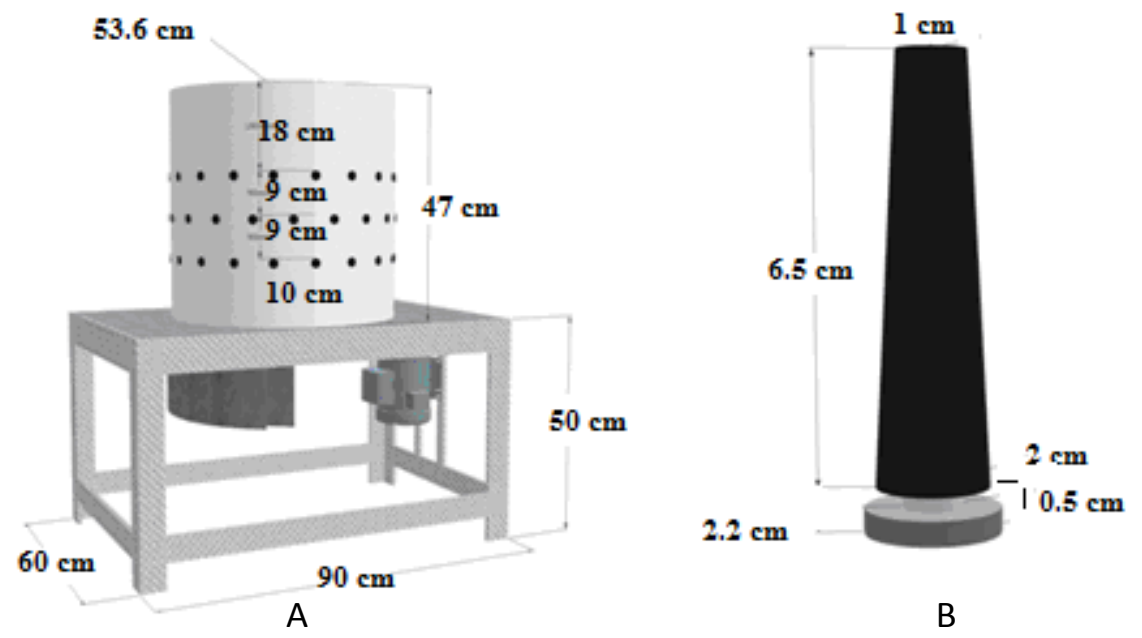

Fig1: Isometric view of chicken de- feather and rubber finger

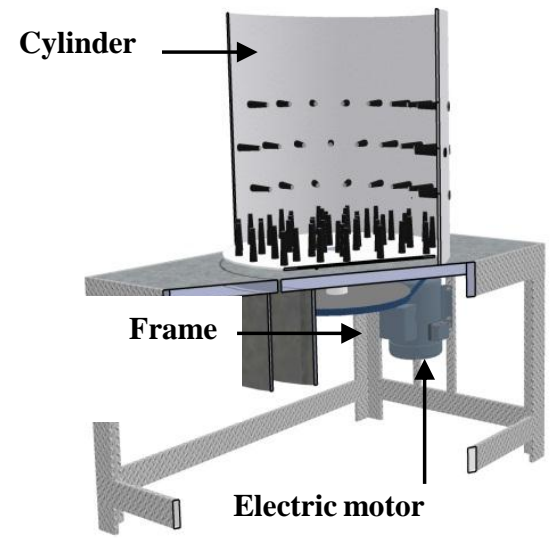

A

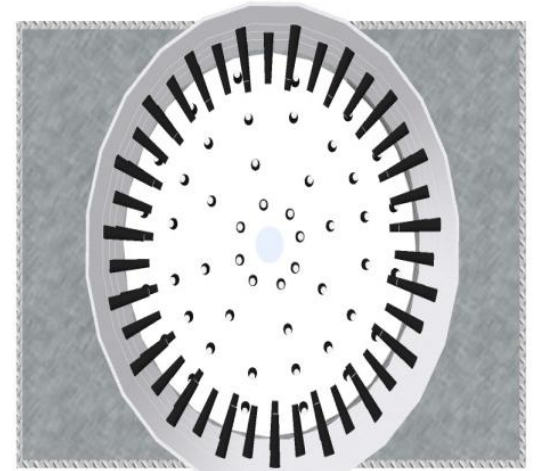

B

Fig. 2: Longitudinal section and plan view of chicken de- feather.

\section{Rotary Speedometer:}

The rotary speed of the de-feather machine was measured using Rotary Speedometer model Telemecanique IP 657. Four drum rotary speeds of 240, 340, 440, 560 rpm were used. 


\section{Balance:}

The balance was used to determine the weight of the live poultry, the weight of the chicken after slaughtering and laying, of a balance with a reading accuracy of $100 \mathrm{~g}$.

\section{Measurements.}

\section{Mechanical and manually plucked feather weight:}

The total machine plucked feather was collected and non- plucked feather on the bird were plucked manually and were weighted using balance $(\mathrm{g})$. The efficiency of the plucking feather machine:

- The efficiency of the plucking feather machine can be calculated as follows:

$$
\eta_{f_{p}}=\frac{W_{m}}{W_{m}+W_{n}} \times 100
$$

Where:

$$
\begin{aligned}
& \eta_{f p}=\text { plucking feather machine efficiency }(\%) ; \\
& W_{m}=\text { weight of feather plucked by machine }(\mathrm{kg}) ; \\
& W_{n}=\text { weight of feather manually plucked after using machine, }(\mathrm{kg}) .
\end{aligned}
$$

\section{The plucking feather productivity:}

Three chicken, the average weight each one $2 \mathrm{~kg}$ were fed into the plucking feather machine for each treatment and the total de- feathering time were recorded (4 in minutes) the machine productivity was calculated as following:

$$
P=\frac{W \times 60}{T}
$$

Where:

P: productivity, $(90 \mathrm{Kg} / \mathrm{h})$;

$\mathrm{W}$ : Average mass of chicken in each treatment, $(6.0 \mathrm{Kg})$;

$\mathrm{T}$ : the total de- feathering time, (4.0 minutes).

\section{The plucking feather machine cost:}

The machine cost was determined by using the following formula according to (Awady, 1978). 
$C=P / h(1 / a+i / 2+t+r)+(W \times e+g+w+R)+m / 150$

Where:

C: machine hourly cost, ( L.E/ h);

P: price of machine, (6000 L.E);

$\mathrm{h}$ : yearly working hours, $(1750 \mathrm{~h})$;

a: life expectancy of the machine, (5 years);

i: interest rate / year, (20\%);

$\mathrm{t}$ : taxes and over heads ratio, $(25 \%)$;

r: repairs and maintenance ratio, $(10 \%)$;

W: required power, $220 \mathrm{~kW} /$ month, $(1.47 \mathrm{Kw} / \mathrm{h})$;

e: electricity cost, $(0.7$ LE. $/ \mathrm{kW} . \mathrm{h})$;

$\mathrm{g}$ : Gaze cost per hour using for scalding time, (5.0 L.E/ h);

w: the price of using water per hour, $(0.67 \mathrm{LE} / \mathrm{h})$;

$\mathrm{R}$ : the rent of the chicken ship $1500 \mathrm{LE} /$ month, i.e. (10 LE./ h);

$\mathrm{m}$ : the monthly average operators wage, 1200 L.E and the monthly average operator working hours, 150 hour.

\section{Operating cost.}

The operating cost (LE./ $\mathrm{kg}$ ) was calculated according to the price of materials in year 2017 by the following formula.

Operating cost $=\frac{\text { Machine cost }, \text { L.E } / \mathrm{h}}{\text { Machine productivity, } \mathrm{kg} / \mathrm{h}}$

\section{RESULTS AND DISCUSSIONS}

\section{Effect of machine rotary speed and scalding time:}

Fig. 3 a and b: Show the effect of machine drum rotary speeds on the mechanical and manually plucked feather weight at different scalding time. Increasing machine rotary speed led to decrease the mechanical plucked feather weight and increase the manually plucked feather weight. Increasing machine drum rotary speeds from 240, 340, 440 and $560 \mathrm{rpm}$ tends to decrease the average of the mechanical plucked weight from $68.2,62.42,56$ and $48.9 \mathrm{~g}$, respectively and increase the manually plucked feather from 18.28, 23.06, 27.9 and $33.3 \mathrm{~g}$, respectively. On the other side, the results indicated that, increasing scalding time from 30, 60 
and $90 \mathrm{sec}$, led to decrease the average of mechanical plucked feather weight from 69.57 to 60.32 and $46.73 \mathrm{~g}$, respectively and increase the manually plucked feather from 17.44 to 24.4 and $35.12 \mathrm{~g}$, respectively. The highest machine plucked feather $80.26 \mathrm{~g}$ was obtained at machine rotary speed of 240rpm and scalding time of $30 \mathrm{sec}$. The least machine plucked feather of $36.5 \mathrm{~g}$ was obtained at machine rotary speed of $560 \mathrm{rpm}$ and scalding time of 90 .

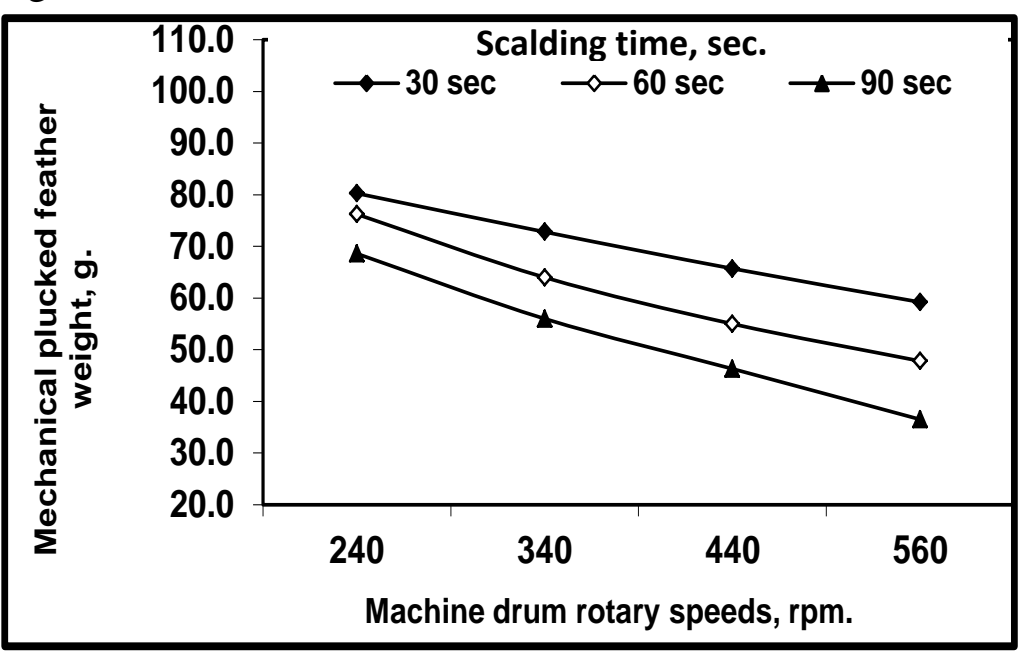

Fig. 3-a: Effect of machine rotary speeds on the mechanical plucked feather weight at different scalding time.

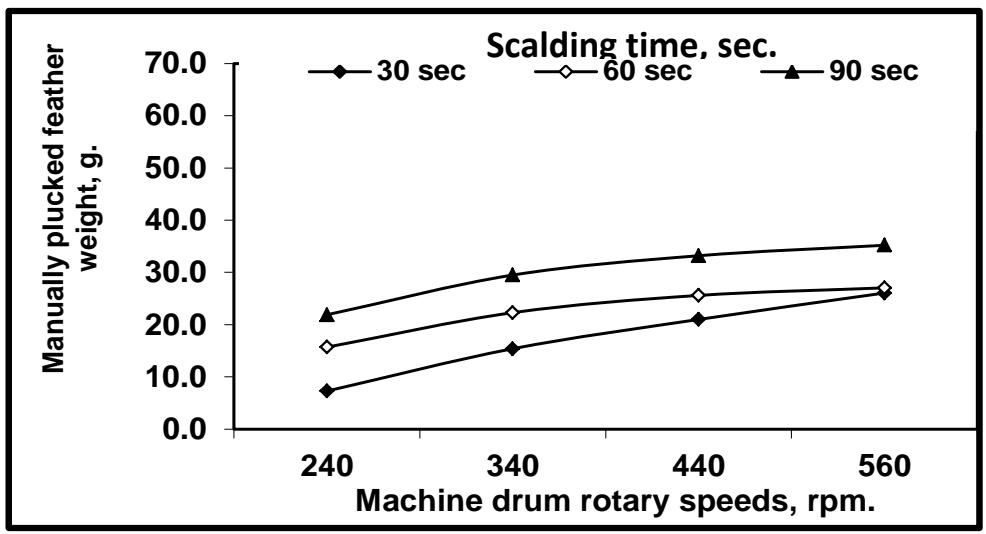

Fig. 3-b: Effect of machine rotary speeds on the manually plucked feather weight at different scalding time. 
Fig. 4: Show the effect of machine speeds on the machine efficiency at different scalding time. Increasing the machine rotary speeds and scalding time tends to decrease the machine efficiency. The results revealed that, Increasing the machine rotary speeds from 240, 340, 440 and $560 \mathrm{rpm}$ led to decrease the average of machine efficiency from 80.9, 74.4, 66.3 and $56.03 \%$, respectively. Also increasing scalding time from 30, 60 and 90 sec, led to decrease the average of machine efficiency from 80.3 to 70.53 and $57.43 \%$, respectively. The highest machine efficiency 91.4 was obtained at machine rotary speed of 240rpm and scalding time of $30 \mathrm{sec}$. The least machine efficiency $43.7 \%$ was obtained at machine rotary speed of $560 \mathrm{rpm}$ and scalding time of $90 \mathrm{sec}$.

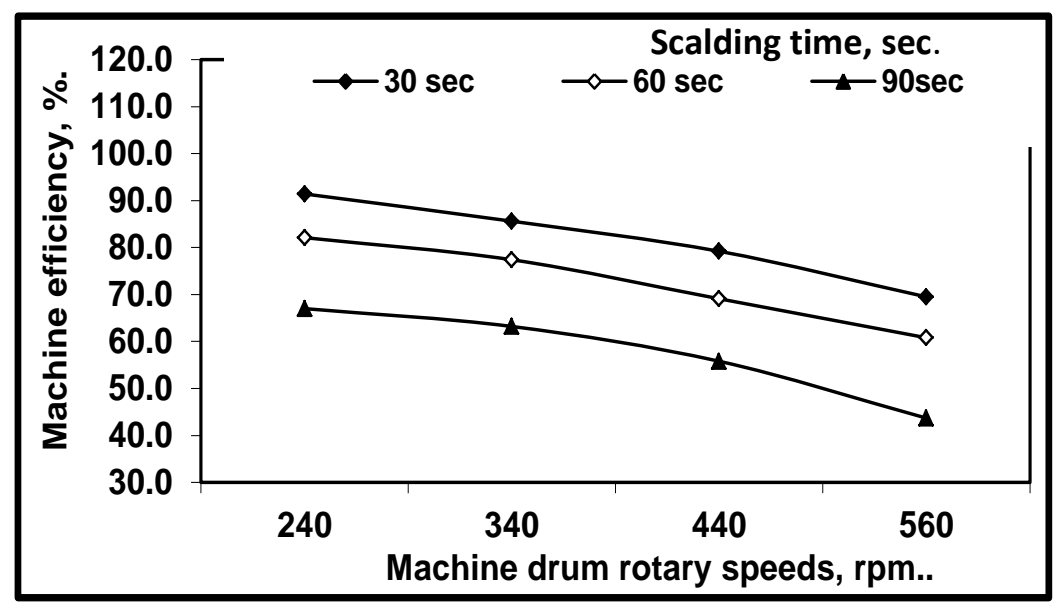

Fig. 4: Effect of machine rotary speeds on the machine efficiency at different scalding time.

\section{Effect of machine drums rotary speed and number of rubber finger:}

Fig. 5: Show the effect of machine speeds on the machine efficiency at different number of machine fingers. The results revealed that, increasing machine rotary speed led to decrease the machine efficiency while increasing number of machine fingers led to increase the machine efficiency. Increasing the machine rotary speeds from 240, 340, 440 and $560 \mathrm{rpm}$ led to decrease the average of machine efficiency from 85.07, $81.1,76.03$ and $69.3 \%$, respectively. But, increasing number of machine 
fingers from 72 to 90 and 108 fingers led to increase the average of machine efficiency from 72.13 to 77.48 and $84 \%$, respectively. The highest machine efficiency 91.4 was obtained at machine rotary speed of 240rpm and number of machine fingers 108 . The least machine efficiency $64 \%$ was obtained at machine rotary speed of $560 \mathrm{rpm}$ and number of machine fingers 72 .

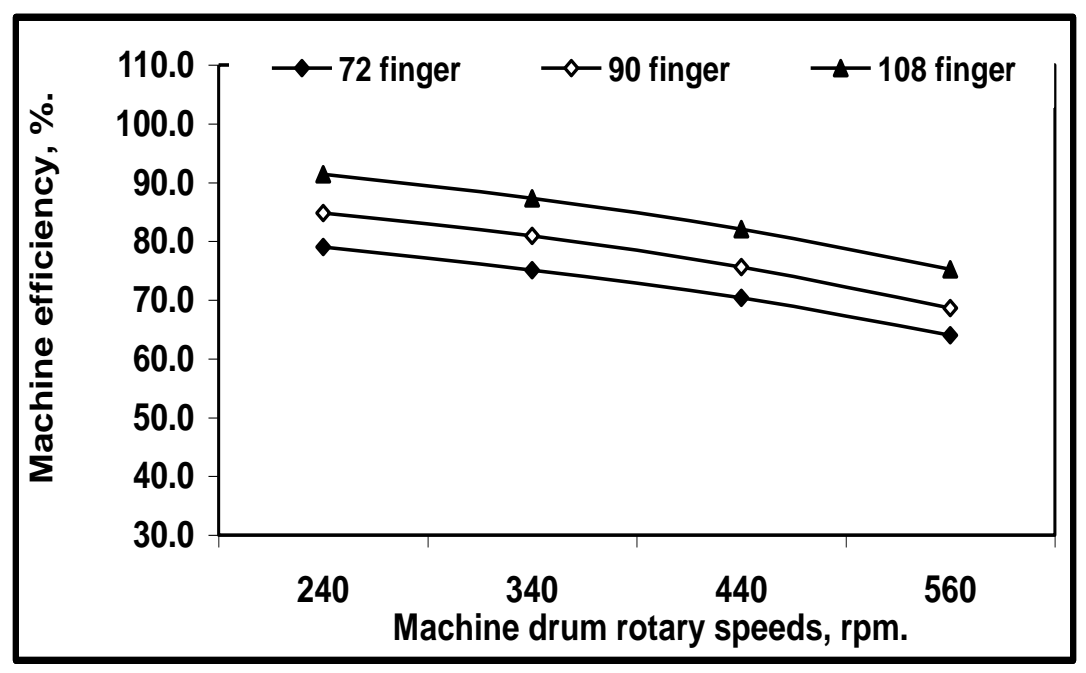

Fig. 5: Effect of machine speeds on the machine efficiency at different number of machine fingers.

\section{Operation cost:}

The operation cost of the poultry feather plucking machine was 0.3 LE. $\mathrm{kg} / \mathrm{h}$, this means that, the operation cost for chicken $(2 \mathrm{~kg}$ ) was $0.60 \mathrm{LE}$., while the owner of the chicken ship take 3.0 LE for the feather chicken, subsequently, the poultry feather plucking machine reduce 2.40 LE for each chicken.

\section{SUMMARY AND CONCLUSION}

The summary of the results obtained on the optimized machine showed that:

1- The machine rotary speed, scalding time and number of machine fingers plays an important role in improving the plucking feather machine efficiency. 
2- Increasing machine rotary speed led to decrease the mechanical plucked feather weight and increase the manually plucked feather weight.

3- Increasing the machine rotary speeds and scalding time tends to decrease the machine efficiency.

4- Increasing machine drum rotary speed led to decrease the machine efficiency while increasing number of machine fingers led to increase the machine efficiency.

5- The highest machine efficiency 91.4 was obtained at machine rotary speed of 240rpm and number of machine fingers 108.

6- The machine drum rotary speed of $240 \mathrm{rpm}$ and scalding time of 30 sec. and number of machine fingers of 108 , could be considered the most suitable for improving machine efficiency.

7- The operation cost of the poultry feather plucking machine was 0.3 LE. $\mathrm{kg} / \mathrm{h}$, this means that, the operation cost for chicken ( $2 \mathrm{~kg}$ ) was 0.6 LE., the poultry feather plucking machine save 2.40 LE for each chicken as compared with the price of the operation cost of the poultry feather plucking in the chicken ship.

\section{REFERENCES}

Adesanya, A. A. and O. J. Olukunle (2015). Development and Performance Evaluation of a Chicken De-Feathering Machine for Small Scale Farmers. Journal of Advanced Agricultural Technologies Vol. 2, No. 1, PP: 71-74.

Adejumo A. O. D1, Adegbie A. M2, Brai S., Oni O. V., Opadijo O. O. (2013): The Effects of Machine and Poultry Parameters on Feather Plucking. Journal of Engineering Research and Applications www.ijera.com ISSN : 2248-9622, Vol.3, Issue 6, Nov-Dec 2013, pp.161-16.

Adetola S.O., G.A. Daramola and S.O. Ogundiran (2014). Development of a Household Poultry De-Feathering Machine with 
Better Efficiency. IOSR Journal of Mechanical and Civil Engineering (IOSR-JMCE) e-ISSN: 2278-1684,p-ISSN: 2320334X, Volume 11, Issue 3 Ver. VIII, PP: 51-59.

Awady, M. N. (1978): Engineering of tractor and Agricultural Machinery. Text BK. Col. Ag. Ain Shams Univ., Misr J. Agric. Eng., 27 (4): 1572-1587.

Buckland, C. (2005): Small scale poultry processing, http//www. FAO. Org. David R.A. (1999). You can build your mechanical plucker. (whizbang) http//www.

FAO. Org.

David R.A. (1999). You can build your mechanical plucker. (whizbang) http//www. FAO. Org.

Hegazy, K. E. S. (2003). Engineering Studies to Improve The Performance of Locally Made Poultry Feather Pluckers. The $11^{\text {th }}$ Annual conference of the Misr. Society of Ag. Eng., 15-16 October, 2003: 666-684.

Ogundipe, S.O. (2002). Animal Production Association of Nigeria. Mechanization Section. Nigerian Journal of Animal Production Farm Vol. 23, pp 102-103.

Jekayinfa, S.O. (2005). Energetic analysis of poultry processing operations. International Journal of Science academic direct. A10, 2005, 077-092.

Lucas E. B. and S. O. Adetola (2013). Comparative Plucking Force Characterization of Chicken Produced From Two Breeds of Chicken. International Journal of Engineering Research and Applications (IJERA) ISSN: 2248-9622 www.ijera.com Vol. 3, Issue 4, pp: 573-579.

Tanimola O. A, P. D. Diabana and Y.O. Bankole (2014). Design and Development of a De-Feathering Machine. International Journal of 
Scientific \& Engineering Research, Volume 5, Issue 6, 208 ISSN 2229-5518, PP: 208-214.

UgwuK. C., S. O. Agu and N. J. Ogbuagu (2015). Optimization and Performance Evaluation of Chicken Feather Plucking Machine. International Journal of Scientific \& Engineering Research, Volume 6, Issue 7, 102 ISSN 2229-5518, PP: 102-108.

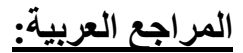

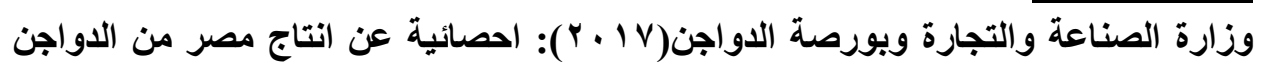
واستيراد مصر من الدواجن

الملخص العربي

تصنيع وتقييم أداء آلة نزع ريش الاجاج محمد عطية على ماضي* عبد الوهاب رمضان عبيه***

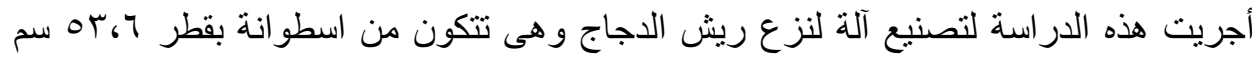

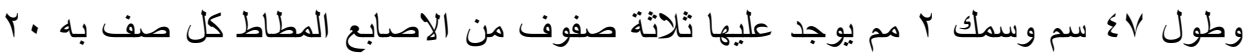

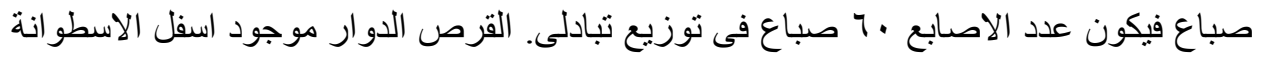

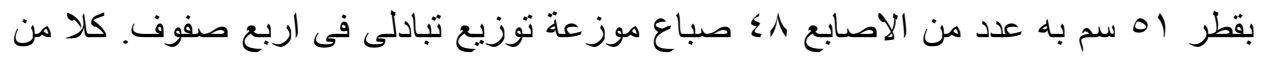

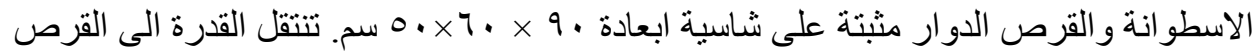

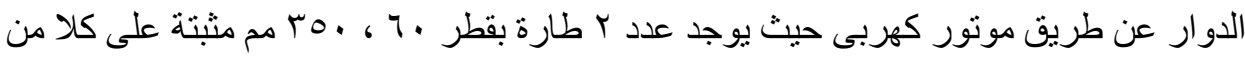

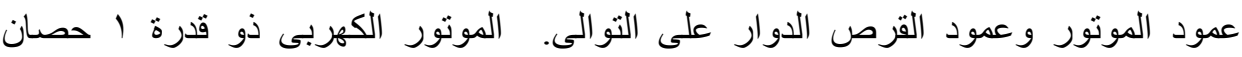

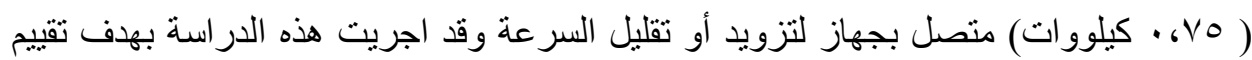

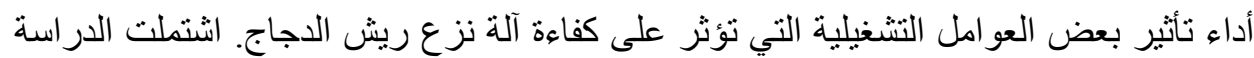

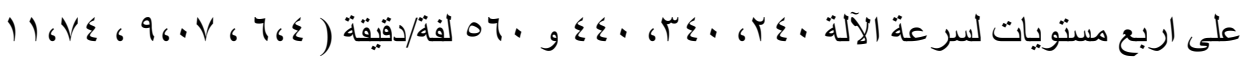

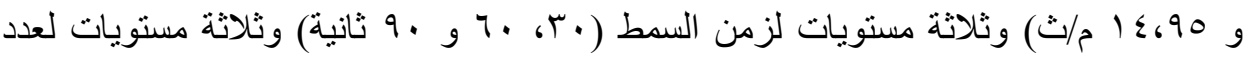

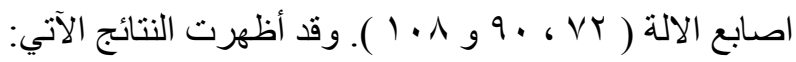

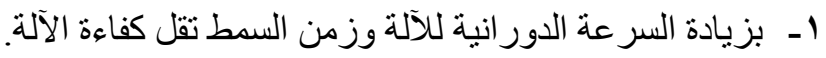

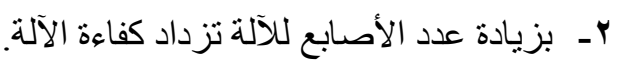

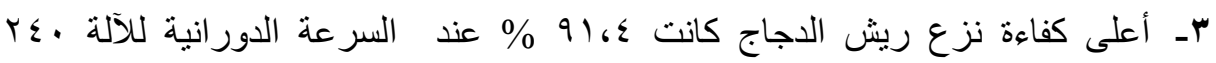

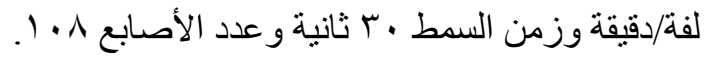

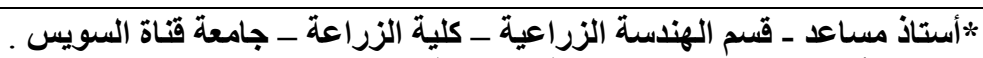
*باحث أول ـ معهل بحوث الهندسة الزراعية ـ الدقي ـ الجيزة. 


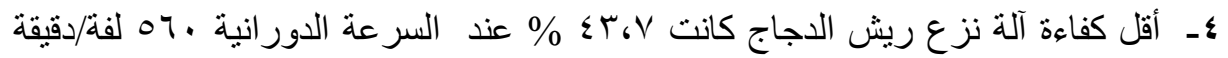
وزمن السمط • 9 ثانية.

هـ ـ بينت النتائج عامة أن سر عة الآلة وزمن السمط و عدد أصسابع الآلة عو امل مؤثرة

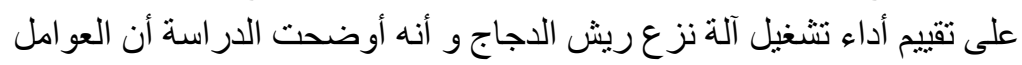

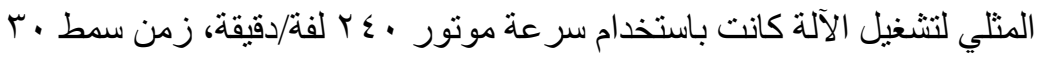
ثنانية و عدد أصابع الآلة 1 • ا أصسابع.

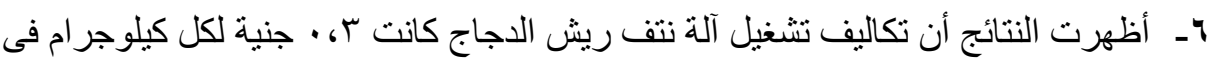

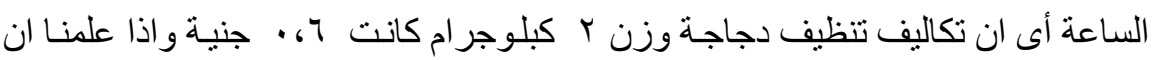

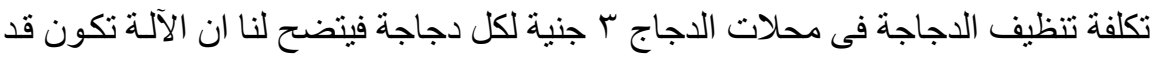

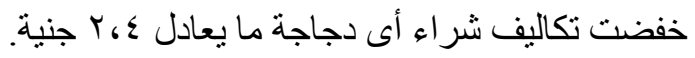

